\title{
IS THERE A PENSIONS CRISIS IN THE
}

\section{UK? ${ }^{1}$}

\section{E Philip Davis \\ Brunel University and NIESR \\ London}

\begin{abstract}
The UK pension system is traditionally seen as offering a good example to other countries, having features such as a low social security burden of the public sector as well as a high coverage of well-financed voluntary private schemes. But recent developments suggest that the model has shown weaknesses. The most pressing current issue is underfunding of defined benefit occupational schemes following the bear market; but there are also the ongoing crises of mis-selling of personal pensions and the failure of Equitable Life insurance company. In this paper we seek to investigate whether there is indeed a crisis and what the locus of the true crisis is. We find that there are important longer-term weaknesses of the UK system as well as these current difficulties, focusing on social security as well as private pensions. Pitfalls faced by UK policymakers offer important lessons to other countries seeking to set up or expand private pension provision.
\end{abstract}

1 This paper was presented in an earlier version as a keynote address for the Japan Pension Research Council meeting, Tokyo, 18-19 September 2003. The author is Professor of Economics and Finance, Brunel University, Uxbridge, Middlesex UB3 4PH (E-mail ‘e_philip_davis@msn.com’, website www.ephilipdavis.com). He is also a Visiting Fellow at the National Institute of Social and Economic Research, an Associate Member of the Financial Markets Group at LSE, Associate Fellow of the Royal Institute of International Affairs and Research Fellow of the Pensions Institute at Birkbeck College, London. The author thanks Isaac Alfon, David Blake, Ian Neale, Mike Wadsworth and participants at the Japanese Pension Research Council conference for helpful comments. The paper also benefited from debate at the LSE Financial Markets Group Regulation Seminar and UK Treasury and Civil Service Committee. Views expressed are those of the author and not necessarily those of the institutions to which he is affiliated. 
Introduction

The UK pension system is traditionally seen as offering a good example to other countries, having features such as a low social security burden of the public sector as well as a high coverage of wellfinanced voluntary private schemes. But recent developments suggest that the model has shown weaknesses. The most pressing current issue is underfunding of defined benefit occupational schemes following the bear market; but there are also the ongoing crises of mis-selling of personal pensions and the failure of Equitable Life insurance company. In this presentation we shall seek to investigate whether there is indeed a crisis and what the locus of the true crisis is. We find that there are important longer term weaknesses of the UK system as well as the current difficulties, focusing on social security as well as private pensions. Pitfalls faced by UK policymakers offer important lessons to other countries seeking to set up or expand private pension provision.

The paper is structured as follows. In Section 2 we briefly note criteria for a sound pension system, while in Section 3 we give key background on the UK regarding demography, public and private pensions. In Section 4 we provide further background on current retirement incomes. Sections 5-11, the core of the paper, examine successively the evidence for a crisis in social security, occupational defined benefit funds, occupational defined contribution funds, personal pensions, annuities, overall saving and asset returns. In Section 12 we look at some additional regulatory issues which are not strictly related to the current crisis. In Section 13, we re-examine the UK system briefly in the light of the criteria set out in Section 2, Section 14 re-evaluates the evidence for a crisis and highlights some potential reforms that could ameliorate the current situation. Note that while we touch on aspects of pension regulation in the UK, this paper is not comprehensive in this respect - for more detail on regulatory issues, see Blake (2003) and Davis (2001).

\section{$2 \quad$ Criteria for a sound pension system}

Before commencing analysis of the UK, we consider it useful to outline certain criteria for an effective pension system - which can be used to judge both the funded and the pay-as-you-go components (see Davis 1998). The most important is clearly retirement-income security - whether the system can indeed generate adequate incomes for those no longer working. But equally important are financing issues linked to sustainability. If a system provides adequate retirement incomes but is likely to become insolvent, it is unsound. More subordinate aspects that may still be of importance are the impact of the system on labour markets and on capital markets. A pension system that can allow for greater economic efficiency, for example by reducing labour market distortions or capital market risk, will help to generate increased economic growth, which will itself provide resources for future pension incomes. We shall return to these in evaluating UK private and public pensions in Section 13. 
Before assessing whether there is a crisis and where it lies, it is essential to provide background information on the UK pension system. Inevitably, such an overview has to be selective; the reader is referred to the extensive data on private pensions in Government Actuary (2003), as well as on pensioner incomes in Department of Work and Pensions (2002a) and the overview of the pension landscape in Pensions Policy Institute (2003) for more detailed information.

\subsection{Demography}

The UK is unusual among OECD countries in having had a relatively old population at an early stage. In 1990 it had the highest ratio of pensioners to those of working age in the G-7. There are currently 10.8 million aged over $65-18 \%$ of the overall population. But the UK is showing slower ageing than most OECD countries. The latest Government projection by 2041 is for the population of 65 and over to be 15.3 million ( $24 \%$ of the total). This is likely to be lower than most OECD countries (for example the UN demographic projections for 1998 showed the same ratio for Japan to be $31 \%$, Germany $29 \%$ and Italy 35\%). The UK will nevertheless, in common with other countries, see a marked shift towards the very old. There is set to be a doubling of the number of very old individuals (over 80 ) from 2.5 million to 4.9 million over same period.

The reason for slow ageing, besides the relatively high level already reached, is a relatively high fertility rate for an OECD country of around 1.8, as well as net immigration, offsetting the rise in longevity. The latter is nonetheless expected to be marked, with life expectancy set to rise from 75 (men) and 80 (women) in 2000 to 80 and 85.5 in 2050.

The burden posed to the economy by such a large portion of older people depends also on the level of labour force participation. In this context, the UK has seen a rise in participation over recent decades as women have tended to enter the labour force while unemployment has tended to decline. For example in $198466.6 \%$ of women were active in the labour market whereas in 2003 it is $73 \%$. On the other hand there has been a marked tendency to early retirement, notably as a consequence of firms seeking to avoid the large accrual of benefits in defined benefit funds close to retirement. This has partly offset the rise in participation for those of working age. According, overall inactivity of those of working age has risen from $19.5 \%$ in 1990 to $21.3 \%$ in 2003 .

\subsection{Pay-as-you-go social security}

Further essential background for evaluating private pensions is provided by the structure of social security pensions. As in all countries, the scope for developing funded private pensions in the UK is 
conditional on the nature of compulsory, pay as you go social security pension provisions. Broadly speaking, the development of social security in the UK has been favourable to private schemes, particularly as a consequence of the rather limited scope of social security on offer and the ability of employees to opt out of earnings related social security pensions.

Since the introduction of the compulsory social insurance scheme, after the Beveridge Report in the 1940s, the UK has offered a basic state pension (BSP), intended to provide a means of subsistence, i.e. largely intended as a form of poverty alleviation. This is a pay-as-you-go pension provided to all those making contributions at a full rate of around $16 \%$ of average earnings at present. Recently, coverage has been extended to those caring for children and the old via the introduction of "home responsibilities protection" credits.

In addition to the BSP there is a State second pension (S2P) for those without a private pension, which currently offers $19 \%$ of average earnings to those making a full set of contributions. However, the number of individuals accruing rights in the S2P is limited, owing to scope for contracting out. As in Japan, this implies that employees with company pensions that 'contract out' have corresponding reductions in employers' social security contributions equivalent to the estimated cost of providing the liability of the earnings related pension via funding. Or for personal pensions, the state rebates a proportion of contributions and pays them into the personal scheme. Since over $50 \%$ of the workforce are in contracted out schemes, only a minority of the workforce are accruing rights in the $\mathrm{S}_{2} \mathrm{P}^{2}$.

A key aspect is that since the 1980s, both forms of social security pension have been indexed to prices and not wages (although there have been some discretionary increases). This means that social security pensions have fallen steadily as a proportion of average earnings, since the latter rise faster than prices. For example, in 1977 the BSP was $20 \%$ of average earnings. There are means tested benefits to keep pensioners above the poverty line, the so-called minimum income guarantee - levels of which rise in line with earnings (they currently guarantee $20 \%$ of earnings). A growing proportion of pensioners are entitled to such additional benefits - around 1.8 million in 2002. The very old, with lower pension accruals, are notably dependent on means tested benefits, with $40 \%$ of those over 90 entitled to them compared with only $12 \%$ of those $65-69$. The take up is not, however, universal. As discussed below, there are important current and future difficulties in this area.

A reform already implemented means that the pension age of men and women will be equalised at 65 in 2020 (till 2010 women retire at 60$)^{3}$, thus generating further savings on top of the price indexation

\footnotetext{
${ }^{2}$ The self employed were initially excluded from S2P - it is proposed in the Pensions Green Paper (Department for Work and Pensions 2002) that they be allowed to opt in to it.

${ }^{3}$ The Pensions Green Paper (Department for Work and Pensions 2002) proposes to abolish compulsory retirement at 65 and allow flexible retirement so individuals can draw pensions and work. This will be done actuarially fairly so cost projections are unaffected.
} 
and future cuts in the S2P (discussed below). Accordingly, the overall projected burden of social security is very low; pension payments (including means tested benefits) will remain around $5 \%$ of GDP according to projections up to 2050 such as EU Economic Policy Committee (2002), with no increase during ageing. This compares with an EU average in mid-century of over $13 \%$ of GDP. Pensions Policy Institute (2003) note, however, that the costs of tax exemptions for private pensions adds another $2.5 \%$ of GDP to this cost at present.

\subsection{Private pensions}

We now turn to a broad assessment of the current state of private pensions in the UK. The system has grown markedly since World War 2, despite provision being voluntary for firms and individuals, owing to the generous tax relief on contributions, the obligation to fund benefits and the abovementioned facility to contract out of earnings related social security. According to our estimates, $64 \%$ of employees are accruing funded pensions, $42 \%$ occupational and $22 \%$ personal, see Table 1 - but coverage of occupational pensions is declining, generally reflecting declines in the coverage in the private sector. Meanwhile coverage of the self-employed is lower at $41 \%$, giving a total coverage of $61.1 \%$.

Table 1: Estimated funded pension coverage in 2000

\begin{tabular}{|l|c|c|c|c|}
\hline & Millions & $\begin{array}{c}\text { \% of employees } \\
\text { in employment }\end{array}$ & $\begin{array}{c}\text { \% of self } \\
\text { employed }\end{array}$ & $\begin{array}{c}\text { \% of } \\
\text { employed }\end{array}$ \\
\hline Defined benefit pension (private) & 4.6 & 19.2 & & 16.9 \\
\hline Defined benefit pension (public) & 4.5 & 18.8 & & 16.5 \\
\hline Total defined benefit & 9.1 & 38.1 & & 33.5 \\
\hline Defined contribution pension & 0.9 & 3.8 & & 3.3 \\
\hline Hybrid funds & 0.1 & 0.4 & & 0.4 \\
\hline Total occupational pensions & 10.1 & 42.3 & & 37.1 \\
\hline Group personal pensions & 2.4 & 10.0 & & 8.8 \\
\hline Individual personal pensions & 2.9 & 12.0 & & 10.5 \\
\hline Total employees in employment & 15.4 & 64.3 & & 56.5 \\
\hline Self employed (personal pensions) & 1.3 & & 41.0 & 4.6 \\
\hline Total employed & 16.6 & & & 61.1 \\
\hline
\end{tabular}

Sources: Government Actuary's Department (2003), PPI (2003), Department of Employment. Note that there were 27.2 million "employed" in 2000 of whom 3.1 million were self-employed and 24 million in "employees in employment". The residue are on training schemes etc.

The key legal feature of occupational funds is that funds should be set up as irrevocable trusts, where a trust is a legal arrangement between persons for the disposal of assets; assets being provided by one person (the settlor) and held by a group of persons (the trustees) for the benefit of another group (the beneficiaries). Thus administration and financial management of assets provided by the employer (settlor) is in the hands of trustees responsible to the beneficiaries, i.e. the members. The trustees must preserve the trust capital and apply it and its income according to the trust deed. As noted, external 
funding is obligatory to obtain fiscal benefits; the only unfunded occupational schemes are for certain public sector employees (civil servants, teachers, police) (Daykin 2002).

As reported by Government Actuary (2003), in 2000 there were 10.1 million employees in occupational pension schemes, of whom 5.7 million were in the private sector and 4.5 million in the public sector. This is well down from the peak of members in 1967 (12.2 million). As in other countries, it is large employers who are most likely to provide occupational pensions; $95 \%$ of employers with over 1000 employees provide a form of pension, while it is only $24 \%$ for those with 5 or fewer employees (Smith and McKay 2002).

The vast majority of occupational scheme members, 9.2 million, are contracted out of the S2P as defined above. 90\% (9.1 million) of occupational pension members in 2000 were still in defined benefit schemes (usually offering $66 \%$ of final salary for a 40 year career) with correspondingly large employer contributions (when funding status warrants such contributions). Defined contribution occupational funds accounted for 900,000 employees (under $10 \%$ of total members) in 2000. A key feature compared with defined benefit funds, as discussed below, is usually lower contributions by the employer.

All personal pensions are defined contribution, and often lack a contribution by the employer. There are two distinct types, group schemes organised on a company basis, thus benefiting from low commissions and some pooling of annuity risk, and individual arrangements with life insurance companies. In 2000, around $10 \%$ of employees were in group schemes and around $12 \%$ of employees were in personal schemes. Coverage of personal pensions is much higher for the self employed, who have no alternative means of provision - around $41 \%$ have personal pensions.

All UK pension funds must be annuitised (except for a tax free lump sum). For defined benefit plans this is usually undertaken directly from within the fund (except for insured funds). For defined contribution funds, both occupational and personal, it occurs via annuity purchase. Staggered annuity purchase is permitted up to age 75 for those in defined contribution plans.

The overall assets of UK pension funds are very large - accounting for over $80 \%$ of GDP in 2001, although the 2002 figure was probably closer to $65 \%$ owing to the $25 \%$ fall in share prices that year. Pension funds account for just under $25 \%$ of UK households' gross financial assets, and together with life insurance account for over $50 \%$. Occupational pension funds are often worth more than company itself in case of older industrial firms with mature funds, such as Rolls Royce.

There is a prudent person rule for asset allocation; building on earlier court cases, the 1995 Pensions Act explicitly gives trustees powers to invest as if they were absolutely entitled to the assets of the 
scheme, and requires them to have regard to the need for diversification of investments and to the suitability of investments, as well as taking proper advice. The prudent person rule has allowed funds to adopt a long term strategic asset allocation which is skewed to equities, giving high long term returns.

Table 2: Asset allocation of G-7 pension funds, 1998

\begin{tabular}{|l|c|c|c|c|c|c|}
\hline & Liquidity & Loans & $\begin{array}{c}\text { Domestic } \\
\text { Bonds }\end{array}$ & $\begin{array}{c}\text { Domestic } \\
\text { Equities }\end{array}$ & Property & $\begin{array}{c}\text { Foreign } \\
\text { Assets }\end{array}$ \\
\hline $\begin{array}{l}\text { United } \\
\text { Kingdom }\end{array}$ & 4 & 0 & 14 & 52 & 3 & 18 \\
\hline United States & 4 & 1 & 21 & $53 \mathrm{E}$ & 0 & $11 \mathrm{E}$ \\
\hline Germany & 0 & 33 & 43 & 10 & 7 & 7 \\
\hline Japan & 5 & 14 & 34 & 23 & 0 & 18 \\
\hline Canada & 5 & 3 & 38 & 27 & 3 & 15 \\
\hline France & 0 & 18 & 65 & 10 & 2 & 5 \\
\hline Italy & 0 & 1 & 35 & 16 & 48 & 0 \\
\hline
\end{tabular}

Source: Davis and Steil (2001)

Table 3: Real returns and risks on pension fund sector portfolios 1970-95

\begin{tabular}{|l|c|c|c|c|}
\hline $\begin{array}{l}\text { Mean } \\
\text { Standard deviation) }\end{array}$ & $\begin{array}{c}\text { Real Returns/ } \\
\text { Risk }\end{array}$ & $\begin{array}{c}\mathbf{5 0 - 5 0 ~ B o n d ~} \\
\text { Equity }\end{array}$ & Global Portfolio & $\begin{array}{c}\text { Real average } \\
\text { earnings growth }\end{array}$ \\
\hline Australia & 1.8 & 3.5 & 6.1 & 1.0 \\
\hline Canada & $(11.4)$ & $(17.5)$ & $(18.2)$ & $(3.4)$ \\
\hline Denmark & 4.8 & 4.0 & 7.1 & 1.3 \\
\hline & $(10.0)$ & $(12.1)$ & $(14.7)$ & $(2.4)$ \\
\hline Germany & 5.0 & 6.1 & 3.7 & 2.4 \\
\hline & $(11.1)$ & $(19.0)$ & $(18.5)$ & $(3.5)$ \\
\hline Japan & 6.0 & 6.4 & 3.9 & 2.7 \\
\hline & $(5.9)$ & $(17.7)$ & $(18.4)$ & $(2.7)$ \\
\hline Netherlands & 4.4 & 6.1 & 6.9 & 2.4 \\
\hline & $(10.2)$ & $(16.9)$ & $(16.0)$ & $(3.0)$ \\
\hline Sweden & 4.6 & 5.5 & 4.8 & 1.4 \\
\hline & $(6.0)$ & $(18.3)$ & $(14.7)$ & $(2.6)$ \\
\hline Switzerland & 2.0 & 8.0 & 6.3 & 1.4 \\
\hline & $(13.1)$ & $(20.1)$ & $(14.8)$ & $(3.5)$ \\
\hline United Kingdom & 1.7 & 2.4 & 3.7 & 1.5 \\
\hline & $(7.5)$ & $(18.1)$ & $(17.0)$ & $(2.1)$ \\
\hline United States & 5.9 & 4.7 & 5.9 & 2.8 \\
\hline & $(12.8)$ & $(15.4)$ & $(15.0)$ & $(2.3)$ \\
\hline
\end{tabular}

Source: Davis and Steil (2001). The 50-50 bond equity column shows returns on a domestic portfolio with $50 \%$ bonds and $50 \%$ equities, while the global portfolio shows a similar asset allocation diversified across OECD markets.

As shown in Table 2 the allocation to equities is higher than elsewhere in the G-7 (foreign assets being mainly equities), while Table 3 shows that the real returns over 1970-95 were correspondingly high. This is the case absolutely, relative to benchmarks such as 50-50 bonds and equities, a global portfolio and the ultimate benchmark for funded pensions, the growth rate of average earnings. This has not 
been the case for many of the other advanced industrial countries, many of whose pension funds are or were over this period subject to quantitative asset restrictions. On the other hand it is not clear whether the high level of equity allocations over the late 1990s was due to calculations of portfolio optimality or a combination of asset managers "herding" into similar allocations so as not to lose mandates and inertia as higher asset returns in equities than other assets drove up the portfolio share.

The downside of such an asset allocation as adopted in the UK has become apparent more recently, in that it has exposed companies (defined benefit) or individuals (defined contribution) to high levels of shortfall risk, as discussed later.

\section{$4 \quad$ Current pensioner incomes}

Before turning to aspects of the current "crisis", we also consider it relevant to assess pensioner incomes, see Table 4. The output of a pension system must ultimately be measured in this way. Current pensioner incomes average $60 \%$ of average earnings (or $44 \%$ for single pensioner). This is higher than in 1979 (when a single pensioner received only 39\%). Currently the main source is the state accounting for $61 \%$ (mainly the BSP and means tested benefits); nevertheless, over half of pensioners receive income from occupational pensions, which accounts on average for $22 \%$ of income.

There is growing inequality among pensioners - the top $20 \%$ (who generally receive sizeable occupational pensions) get on average $87 \%$ of average earnings, while the bottom $20 \%$ only obtains the equivalent of $21 \%$ of average earnings. Such inequality may increase in coming years since a falling proportion of new retirees are getting occupational pensions. The very old, female, and the self employed are often still in relative poverty owing to inadequate pension provision, although much less so than in 1979.

\section{Table 4 Income sources for single pensioner}

\begin{tabular}{|l|c|c|}
\hline & $£$ & Percent \\
\hline State benefits & 112 & 61 \\
\hline Occupational pension & 41 & 22 \\
\hline Investment income & 19 & 10 \\
\hline Earnings & 9 & 5 \\
\hline Other income & 2 & 1 \\
\hline
\end{tabular}

Source: DWP (2002)

We now turn to an assessment of whether there is a crisis in various areas of the UK pension system, with a particular focus on private provision. But first we consider whether there is a crisis in social security. 
Is there a crisis in social security?

As noted, there are no fiscal financing problems now or on the horizon if the current system is maintained. There will in future be some increase in the proportion qualifying for BSP (owing to home responsibility protection) - but the level of the BSP is already below the official poverty line, so those on full BSP pensions alone are entitled to income support (the minimum income guarantee now replaced by the pension credit). One issue is that such income support is not always taken up, leaving some pensioners in relative poverty. A further, more systemic problem is that income support has a non pension income test, such that benefits are withdrawn when incomes accrue. This discourages saving by low income worker. Although the system has been reformed to reduce the very high losses that formerly occurred, there is still a deduction rate of $40 \%$ of investment income from benefits. And the level of means tested benefits is likely to rise faster than state pensions. A consequence is that financial institutions are reticent in selling pension products to those lower down the income distribution in case they are accused in future of mis-selling as means tested benefit levels rise above the individual's retirement income.

A coming crisis over the longer term arises from the ongoing decline in replacement rate (of BSP and S2P) due to price indexation, as well as earlier reforms dating from 1986 which reduced the accrual factor of SERPS, the predecessor of S2P (Davis 1997). As shown in Table 5, the combined replacement ratio at average earnings of state pensions is set to fall from $35 \%$ today to $25 \%$ in 2040 , and with the proposed shift of S2P to flat rate from an earnings related basis, it would fall further to $20 \%$ (PPI 2003). This implies a two fold future crisis - a growing burden on the state of means tested benefits, with their ongoing disincentives for saving, and possible pensioner poverty among those who do not take up means tested benefits.

\section{Table 5 Social security replacement ratios}

\begin{tabular}{|l|c|c|}
\hline$\%$ of average earnings & 2000 & 2040 \\
\hline Basic state pension & 16 & 9 \\
\hline S2P (current) & 19 & 16 \\
\hline S2P (proposed flat rate reform) & 19 & 11 \\
\hline
\end{tabular}

Source: PPI (2003)

\section{$6 \quad$ Is there a crisis in defined benefit occupational pensions?}

In occupational defined benefit funds, the key current issue is underfunding. Current estimates suggest there were pension fund deficits at end-2002 of $£ 160-300$ billion (CBI 2003), relative to the accrued benefit obligation. Some firms such as the grocery chain Sainsbury having funding ratios as low as $65 \%$. The Economist (2003a) reports estimates that suggest average funding levels for the top $100 \mathrm{UK}$ companies fell from $120 \%$ in 2001 to $80 \%$ at end-2002. Many companies have deficits of over $40 \%$ of 
their market capitalisation. The overall deficits are equivalent to $2-3 \%$ of GDP or 3-5\% of estimated pension fund assets at the end of 2002 .

There are a number of underlying factors: most fundamentally, there is the bear market which hit pension funds in the UK, given large holdings in equities (Table 2). The UK market at end-2002 was some $50 \%$ below its peak in 2000 (Davis 2003a). The degree of underfunding was, however, aggravated by earlier government policies which had raised the accrued benefit obligation, notably compulsory indexation up to $5 \%$ of current and deferred pensions. This policy was not independent of the issues of social security, in that it can be argued that such indexation was essential given the very low levels of socials security pensions - unlike for example in the US where more generous social security offers adequate indexed benefits. Furthermore, tax policies, notably limits on overfunding to $5 \%$ encouraged holidays from contributions by employers in the previous bull phase, when they should have been building up reserves during a period of historically abnormal asset returns. (This point can be overstressed, as actuarial assumptions are sufficiently flexible to allow a high level of funding.) More recently, declining bond yields and rising longevity have also been raising liabilities.

The strong influence of bond yields on funding levels is a relatively recent phenomenon. Until 1997, an actuarial basis of funding calculation was used both for regulatory and accounting purposes. This was based on a sustainable income basis for assets and partly-equity based discount rate for liabilities. A bear market would influence funding levels mainly via the impact on prospective dividends. There has since been a switch to use of a current market value basis for assets (plus prospective asset yields) and corporate bond yield discount for liabilities.

This shift was reflected initially in the uniform Minimum Funding Requirement (MFR) introduced in the 1995 Pensions Act, before which there were no regulatory funding requirements. The calculations under the MFR are made on the assumption of ensuring sufficient assets are available if the scheme is wound-up, to buy out pensioners benefits with an insurance company and provide non-pensioners with a fair actuarial value of their accrued rights that may be transferred to an alternative pension vehicle (although as noted by Blake (2003) it may still fall short of the full cost of buying deferred annuities to cover obligations). Valuations are made every three years, and liabilities (the accumulated benefit obligation) are valued by reference to a "benchmark portfolio" of UK government bonds and equities, with the proportion of government bonds in the benchmark increasing as the scheme matures. The system requires shortfalls be corrected in 3-10 years, depending on severity. The requirement to match government bonds had the paradoxical effect of leading to excess demand for these securities by pension funds (while the UK government was in surplus), driving down yields and raising liabilities.

From 2005 the accounting standard FRS17 will require pension deficits to be declared on the balance sheet at current market prices, with liabilities (the accrued benefit obligation) valued according to an 
AA corporate bond based benchmark. Firms are already declaring their FRS17-based deficits, while rating agencies declare that such deficits count as debt. This implies a marked impact on credit ratings. Firms with defined benefit funds also face a burden of topping-up assets to match liabilities. (The UK employer organisation the CBI (2003) project a doubling of 2000 contributions will be needed by 2005.) This in turn will limit dividends and fixed investment - and hence could affect overall UK economic growth.

Deficits have brought a broader of awareness of risks from defined benefit obligations to CEOs. They also highlight that the overall burden of regulation has increased since the mid-1980s. The consequence has been closure of most defined benefit schemes to new entrants, although the effect on the accrued benefit obligation is minimal (as existing employees continue to accrue rights). By 2002, $50 \%$ of defined benefit funds had closed to new members. There is a paradox in that similar shortfalls were seen in the 1970s and made up in the early 1980s without structural shift in the form of pension provision.

The bear market has ignited a debate on whether pension liabilities are better covered with bonds (the pharmaceutical company Boots made a successful switch when bond yields were relatively high) - but costs are seen as likely to be higher. Nevertheless, a shift to bonds is underway reflecting scheme maturity, and enhanced shortfall risk under MFR/FRS17, see Davis (2001).

The crisis in occupational pensions has had a wider effect than on new entrants to defined benefit funds, who are those directly affected. At the time of writing there is a generalised loss of confidence in company pensions. A further reason for this - and a problem for retirement income security in itself - is the conduct of wind-ups. 10,000 plans have been wound up since 1997, affecting 300,000 members. As noted, the full MFR funding level is insufficient to buy deferred annuities. Even if they are fully funded they will not provide sufficient assets to fulfil all obligations, and many are underfunded. A loophole in the law has meant that even solvent employers are entitled to wind up schemes with only the benefits that MFR funding provide. In this context, a further concern has also arisen from realisation that under current law, pensioners' interests during a wind-up have absolute priority over workers. So a wound up pension scheme may provide full ongoing pensions but very little for workers on the point of retirement. A case that brought these problems together is that of the UK subsidiary of the Danish shipping group Maersk. Although solvent, it sought to wind up its fund with only MFR minimum assets. Some workers would have been deprived of $60 \%$ of their rights, given pensioner priority. In November 2003 Maersk decided to fully fund all obligations, following adverse publicity and appointment of an employee trustee at the behest of the regulator OPRA.

There has been a regulatory response to the problems highlighted above, but its appropriateness is questionable. The MFR is now being replaced as announced in the Pensions Green Paper (Department 
for Work and Pensions 2002). The proposed replacement is to be a long-term scheme-specific approach based on transparency and disclosure, with no reference assets. Funds will have to disclose the value of assets, portfolio distributions, planned future contributions and asset allocation, assumptions on asset returns and valuation of assets, and justification of asset allocation and investment return assumptions in the light of sponsors and the funds' situation. There will also need to be explanation of implications of volatility of assets for risks of under funding, justifying why this is acceptable. Mercer (2003) comments that since the details are left to be resolved by the actuarial profession, and there is no guarantee it will lead to improved funding.

Furthermore, the government has announced the introduction of pension insurance to cover benefits in insolvency and not just fraud as hitherto, financed by an ex post levy on solvent funds. Such a system is likely to face the difficulty of moral hazard, i.e. that it may create incentive structures leading honest recipients to undertake excessively risky investments, which in turn give the risk of large shortfall losses to the insurer. In other words, losses may not arise merely from fraud or incompetence but the incentive structure itself - a problem often thought to arise in the US, where a major crisis of underfunding with large government liabilities was foreseen in the early 1990s similar to that for Savings and Loans associations (Bodie 1992). It could lead to a further flight from defined benefit funds as solvent funds fear being "taxed" to pay for insolvent ones.

A tax simplification from the current 20 regimes will aid pension transparency and seems a positive measure (Inland Revenue 2002). But it has also been announced that there will be a limit of £1.4 million in the value of a pension fund, either for defined benefit or defined contribution plans. Since this will be indexed to prices, it will increasingly penalise senior or even middle management. Once a pension scheme becomes unattractive to senior employees, its demise may well be accelerated.

One key area where improvement is needed is education of pension trustees. It is widely suggested that trustees are inadequately educated on investment matters and hence become dependent on the large consultants for decisions on asset allocation. This is confirmed by Government Actuary (2003) who showed that on average $75 \%$ of schemes had no trustees qualified or recently trained in investment matters, although for large schemes with over 10,000 members it was $21 \%$. As noted in Economist (2003b) the consultants in turn were advocates of the high equity exposures from which funds now suffer, as well as costly but unremunerative active management instead of passive (Blake 2003). In his recent report for the government on shortcomings in institutional investment, Paul Myners (2001) pointed to the lack of investment skills among trustees of most pension funds, which was seen as contrary to satisfactory scheme governance. Notably, taking advice without ability to evaluate it was seen as contrary to effective decision making by trustees. Myners recommended that trustees should be paid and should acquire appropriate investment skills - albeit without proposing legislation at this stage. 
In questioning the difficulties of defined benefit funds, it must be noted that defined contribution funds are in principle better for a mobile workforce since there are losses from changing jobs. As shown by Blake and Orszag (1997) changing jobs 6 times in a career with a typical defined benefit fund loses $25 \%$ of benefits, despite indexation of deferred benefits. It is to issues for defined contribution funds we now turn.

\section{$7 \quad$ A crisis in occupational defined contribution funds?}

Whereas there are by definition no deficits in defined contribution funds, asset risk to the employee is greatly increased compared to defined benefit funds. In principle, with identical contributions to defined benefit, such risks are offset by reduced losses in changing jobs. But there is not a level playing field, owing to inadequate contributions to defined contribution schemes. Average contributions, as shown in Table 6, are much lower for defined contribution funds, both by employer and employee. And indeed, when employers close defined benefit funds, contributions may fall. This points to the risk of a future crisis of inadequate future retirement income, especially given rising longevity, to add to the heightened investment risk and uncertainty for members.

Other difficulties of occupational defined contribution schemes are lower incentives by employers to optimise investment, given they do not bear risks (as witness for example the low returns for funds in Switzerland and Australia in Table 3). Risk benefits such as life and disability insurance are generally less generous than with defined benefit funds, typically being based only on accrued contributions (Government Actuary 2003).

Table 6 Average contributions for occupational pensions

\begin{tabular}{|l|c|c|c|}
\hline Percent of salary & Employer & Employee & Total \\
\hline Defined benefit & 11.1 & 5 & 16.1 \\
\hline Defined contribution & 5.1 & 3.4 & 8.5 \\
\hline
\end{tabular}

Source: Government Actuary (2003)

\section{$8 \quad$ A crisis in personal pensions?}

For personal pensions there is the ongoing issue of the resolution of mis-selling of personal pensions in 1980s and early 1990s. Government is not immune to criticism - the crisis occurred after the then government had offered incentives for their purchase with an extra rebate of national insurance contributions, to reduce the social security burden. Also it can be argued that government legislated to end compulsory membership of occupational funds, abrogating freely agreed collective bargains between employers and employees, and thereby left members of occupational funds prey to personal pension salespersons. 500,000 individuals were persuaded by commission-driven salesmen to leave 
occupational funds, of whom $90 \%$ received inappropriate advice (owing to high transfer costs and no employer contribution). The response has been massive fines on insurance companies and tightening of regulations on selling. This issue continues to affect confidence in personal pensions, compounded by comparable concerns over misselling of endowment insurance policies to back mortgage loans for house purchase.

But there are deeper issues which vitiate personal pensions in the UK as a vehicle for retirement income. One is inadequate contributions - many only pay in the so-called contracted-out rebate from social security (4.6\%). Even more than for occupational defined contribution funds, there is a total lack of risk benefits such as life and disability insurance usually included in occupational defined benefit funds. Commission charges are so high as to use up most of the return, especially for small funds - in traditional personal pensions they account for $2.5 \%$ of contributions and $1.5 \%$ of assets, although Alfon (2002) suggests they have fallen recently. The fees are frontloaded, making them particularly deleterious to returns. Blake (2000) suggests that they are equivalent to a $10-20 \%$ cut in contributions, compared to a typical $5-7 \%$ for occupational funds.

Furthermore, there are a costs of switching between funds, owing to transfer and new upfront fees, amounting to $25 \%-33 \%$ according to Blake (2000) These are particularly problematic given that poor performance among funds tends to be persistent, and funds take time to close (Lunde, Blake and Timmerman 1999). Meanwhile, where there is a company scheme, employers will not contribute to personal pensions of their staff who have left that scheme. So the overall issue is again inadequate retirement income in future.

Recently, belatedly, there has been some government response to these issues, notably the launch of stakeholder pensions with charges (including commissions) limited to $1 \%$ with no initial commissions ${ }^{4}$. As argued by Cook and Johnson (2000) of the FSA, only with such limits will personal pensions be more advantageous than non-pension savings vehicles (so called investment savings accounts) which do not offer tax relief upfront. They will also lead to an increase in portfolioindexation of pension assets, which given the lower charges and poor performance of active managers (Blake 2000) will be of benefit to beneficiaries. But there has been marked resistance by sellers who claim low fees make advice uneconomic and a poor take-up by public, especially the low paid for whom stakeholders were designed. As noted, sellers are also concerned that the existence and possible future shifts in means testing implies sale of stakeholder might not be "best advice", exposing them to further fines for mis-selling.

\footnotetext{
${ }^{4}$ The Sandler Review (HM Treasury 2002) proposed a wider range of such simple products at low commissions.
} 
A crisis in annuities?

In the UK there is mandatory annuitisation - justified in turn by tax privileges and possible moral hazard as lump sums are dissipated leaving a burden on the state. Issues relating to annuities are of particular relevance given the ongoing shift to defined contribution funds as the key pillar of retirement incomes (see Neale 2000).

There is currently public concern over the declining level of annuities from defined contribution funds, particularly when government bond yields fell close to 3\% in early 2003. As noted, such low interest rates were themselves partly a consequence of hedging by pension funds against shortfall risk in face of the MFR/FRS17. The recent slight recovery in yields may reduce concerns arising from this source. Of course there is a degree of money illusion in that real rates are most relevant to long term income. Furthermore, we note that the degree of interest rate risk in annuities is dependent on the portfolio held prior to retirement - if it was long term bonds, interest rate risk would be minor (Valdes Prieto 1998). So again inappropriate asset allocation to equities close to retirement may be part of the problem.

Among analysts, there are more justifiable concern over solvency risks to insurance companies from the rush into high risk, high yield bonds as government bond yields fell, herding into credit derivatives, and underestimation of longevity (Davis 2002a). Also despite mandatory annuitisation, there remains adverse selection to annuitants owing to voluntary nature of private pensions (those choosing to have defined contribution pensions may be those who know they will be long-lived). This means that insurance companies charge extra for annuities compared with an actuarially fair rate for the whole population.

Then there has been the Equitable Life crisis leading to loss of confidence in annuities - and life insurance companies who are largely responsible for running personal pensions. The events are comparable to those suffered recently by Japanese life insurance companies (Fukao 2002), in terms of failure of reserving and pricing of annuities. It would appear that the company gave the option of deferred guaranteed annuities (promising a minimum return on retirement) during the period 19571988 to a large number of personal pension savers. This was apparently done without extra charge and with no specific reserves held to cover the cost of the guarantees. It also disregarded the history of the long term bond market, when bond yields were often below the rates promised - a particular paradox given Equitable itself was the oldest life company dating back several centuries.

Over this period the embedded option was never "in the money" since market rates were always above the guaranteed rates. However, in 1993 the market rate fell below the guaranteed rate, and the guarantees began to have an intrinsic value. Other insurance companies that had sold such policies dealt with the implicit mortality and interest rate risks in the guarantees in various relatively prudent 
ways. For example, they reserved for them, reinsured them, bought them out, capped them or put them in an orphan fund to run off. Instead, Equitable sought to manage them by discretion, by paying a smaller final bonus to those with-profits investors who sought to retain their guarantee, as compared to those willing to give it up. The attempt to pay lower bonus to guarantee holders was quashed in court leading to an attempt to place the burden on the whole with profits fund (as Equitable was a mutual, these are in effect the shareholders). There are policy lessons for reserving (taking account of option values) and fund separation. Again, confidence in saving has been affected by the Equitable debacle far beyond its immediate financial consequences.

Problems of information provision to consumers regarding annuities are meanwhile worsening retirement income security. Consumers with defined contribution funds face a plethora of choices at retirement. These include the term of the annuity; the type of annuity - whether level or inflation linked; the timing of payment; and the choice of company given defined contribution funds have the "open market option" to buy annuities from any company. In this context, FSA (2002a) comment that consumer understanding of annuities is very low and people do not fully understand the risks of the decisions they are taking. The open market option is rarely exercised although shopping around could gain a 35\% increase in income. Second, there is money illusion with individuals buying level annuities when index linked would give better protection over the long term. Often individuals delay purchase of an annuity, although such a strategy is vulnerable to "mortality drag" where lower mortality at a later date implies lower annuity rates, as well as high commission rates. Finally, very few individuals were buying impaired life annuities, which could offer a higher income, although $40 \%$ were eligible (due to health conditions, smoking history etc.).

In response to these concerns, the FSA is introducing consumer advice literature and also obliging firms selling annuities to inform consumers of their open market rights. Stringent qualifications and disclosure are required of salesmen, in the light of earlier mis-selling scandals in the personal pensions field. Best advice must be offered for the circumstances of the individual, and cooling off periods during which the individual may change their mind. As noted by Cardinale et al (2002), the regulatory regime is so severe that many annuities are sold execution-only with individuals receiving little or no financial advice. Given the tough regime and low commissions arising from the small size of maturing personal pensions, the level of interest among advisers in getting such business is low. Again this helps to explain why most individuals take annuities from their pension saving provider. And a larger proportion of these go for level annuities ( $90 \%$ compared to $80 \%$ who buy in the open market), which may not, as noted, be the best option. 
Rising longevity, the low public pension and declining employer provision puts the onus on individuals to save for retirement. But in fact overall contributions to private pensions in 2001 were only $7.7 \%$ of average earnings. $42 \%$ of workers are only occasional members of schemes - mainly lower income earners. Younger workers most likely not to contribute, although returns are highest see Table 7. One reason for this may be the growing burden of student debt which is crowding out the most remunerative early pension contributions (Davis 2003b). This will be aggravated by currentlyproposed increases in student fees. Oliver, Wyman (2001) argue that advice is crucial in encouraging individuals to save, especially those at lower incomes. As noted elsewhere, advice provision is seen as uneconomic by many providers.

Table 7: Coverage of private pensions by age

\begin{tabular}{|l|c|}
\hline age group & percent \\
\hline $16-24$ & $21 \%$ \\
\hline $25-34$ & $56 \%$ \\
\hline $35-44$ & $65 \%$ \\
\hline $45-54$ & $68 \%$ \\
\hline $55-59$ & $58 \%$ \\
\hline $60-64$ & $44 \%$ \\
\hline
\end{tabular}

Source: PPI (2003)

Beyond pensions, non-pension saving is low; the UK saving ratio has been low since financial deregulation in the early 1980s (see Table 8), partly as a consequence of high level of mortgage borrowing. This is reflected in non-pension assets. The non pension balance sheet of the average household has net assets of $£ 13,649$, of which $£ 7,786$ are in securities. But $25 \%$ have negative net financial wealth and $50 \%$ have net wealth below $£ 1,500$. It is notable that average non pension wealth is only $£ 5,357$ for those without an occupational pension; and $48 \%$ of those without a pension have negative net financial wealth. Hence they do not have substitute sources of funds for retirement. Over 2000-3, gross financial wealth of the household sector fell by $17 \%$ and net financial assets by $32 \%$, suggesting these figures have worsened.

Table 8: Personal saving ratio

\begin{tabular}{|r|c|}
\hline & Percent of personal disposable income \\
\hline $1963-1972$ & 6.2 \\
\hline $1973-1982$ & 9.8 \\
\hline $1983-1992$ & 8.5 \\
\hline $1993-2002$ & 7.5 \\
\hline 2000 & 4.3 \\
\hline 2001 & 5.7 \\
\hline 2002 & 4.7 \\
\hline
\end{tabular}

Source: www.statistics.gov.uk 
Surveys suggest there is a major underestimation of saving needs for retirement - and most individuals focus on pensions only 10 years ahead of retirement (FSA 2002b). It has been calculated that 13 million individuals will get a pension below $2 / 3$ of their final earnings, and 3 million less than half implying a "savings gap" of $£ 27$ billion a year, at plausible rates of return which would entail a 54\% increase in current accumulation rates (Oliver, Wyman 2001). More recent work by JP Morgan quoted in Financial Times (2003) suggests that as many as 50\% of the workforce could get a pension of less than $40 \%$ of their salary. Of course, such estimates are sensitive to assumptions on earnings growth and asset returns but the overall shortfall in pension saving is undeniable.

We would suggest that the savings gap is aggravated by some of the crises outlined above - including the deficits and closure of defined benefit funds, loss of confidence in personal pensions and life insurance generally following mis-selling and Equitable Life. Furthermore the issue of means testing, which continues with the pension credit, is weighing on saving for those of lower income.

One option to improve the situation is to facilitate liquification of housing wealth ( $80 \%$ of $45-64 \mathrm{~s}$ are owner occupiers). While trading down is feasible it incurs substantial costs, and the reverse mortgage market is poorly developed. According to Mike Wadsworth of Watson Wyatt (personal correspondence), the reverse mortgage products in the UK typically pay out a lump sum and not an annuity. To the extent that this money is invested, returns are subject to tax but there is no corresponding tax relief on the interest payable to the lender. The reverse mortgage products in the UK are generally offered on a fixed rate of interest - currently circa $7 \%$ pa - above mortgage rates. While the products typically carry a 'no negative equity' guarantee (thus there is no possibility of eviction but a higher rate as a risk premium) and even if the tax disadvantage referred to above is not present, there is a value for money question about borrowing at say 'labour earnings increase $+3 \%$ ' against an asset, namely housing, the value of which over the longer term has increased broadly in line with labour earnings. Perhaps in a UK context the main financial argument for such products is mitigation of inheritance tax on assets remaining at death of $40 \%$ above a threshold of currently $£ 255,000$ although most sales appear to date to be related to alleviation of hardship. Another reason for such a low return is that the incentives for old people to continue to maintain their houses may not be great, if the selling price has already been established. This may argue for an equity sharing arrangement.

But also there is a need to prevent means testing for social benefits from discouraging private saving and to stop frequent change in government policy from generating uncertainty, discouraging saving overall. Resolution of the current crises will help to rebuild public confidence in the savings industry generally. 
We have seen that UK funded pensions, focused on equities, are strongly affected by the low level of asset prices. The current issue of underfunding will be resolved if the bear market ends rapidly, while higher share prices will also boost the potential annuity that can be purchased with defined contribution funds. But the experience of 1974 showed that real equity prices can take a protracted period to recover, see Table 9. In the UK, real equity prices recovered their previous peak in $1987-$ and for the US and Canada in the 1990s. If repeated, such performance would imply a prolonged delay - or huge expense - before deficits are eliminated.

Table 9 Share price behaviour following the 1972-4 economic and financial crisis

\begin{tabular}{|c|c|c|c|c|c|c|c|}
\hline & UK & US & Germany & Japan & Canada & France & Italy \\
\hline Peak of share prices & Aug-72 & Dec-72 & Jul-72 & Jan-73 & Dec-72 & Apr-73 & Jun-73 \\
\hline $\begin{array}{l}\text { Fall to trough in nominal } \\
\text { terms (date of trough) }\end{array}$ & $\begin{array}{l}68.5 \% \\
\text { (Dec- } \\
74)\end{array}$ & $\begin{array}{l}48.4 \% \\
\text { (Sep- } \\
74)\end{array}$ & $\begin{array}{l}34.4 \% \\
(\text { Sep-74) }\end{array}$ & $\begin{array}{l}40.2 \% \\
(\text { Oct } \\
74)\end{array}$ & $\begin{array}{l}35.5 \% \\
\text { (Sep- } \\
74)\end{array}$ & $\begin{array}{l}52.7 \% \\
\text { (Sep- } \\
74)\end{array}$ & $\begin{array}{l}42.9 \% \\
(\mathrm{Dec}- \\
74)\end{array}$ \\
\hline $\begin{array}{l}\text { Return to original nominal } \\
\text { level }\end{array}$ & Sep-77 & Nov-80 & Mar-76 & Jan-79 & Jan-79 & Sep-79 & Oct- 80 \\
\hline $\begin{array}{l}\text { Fall to trough in real terms } \\
\text { (date of trough) }\end{array}$ & $\begin{array}{l}77.2 \% \\
\text { (Dec- } \\
74)\end{array}$ & $\begin{array}{l}56.1 \% \\
\text { (Sep- } \\
74)\end{array}$ & $\begin{array}{l}43.0 \% \\
(\text { Sep-74) }\end{array}$ & $\begin{array}{l}56.2 \% \\
\text { (Oct- } \\
74)\end{array}$ & $\begin{array}{l}46.7 \% \\
\text { (Dec- } \\
74)\end{array}$ & $\begin{array}{l}68.1 \% \\
\text { (Apr- } \\
77)\end{array}$ & $\begin{array}{l}82.4 \% \\
\text { (Dec- } \\
77)\end{array}$ \\
\hline Return to original real level & $\begin{array}{l}\text { May- } \\
87\end{array}$ & Aug-93 & Jun-85 & Feb-85 & Oct-96 & Aug-86 & Aug-86 \\
\hline
\end{tabular}

Source: Davis (2003a)

The time taken to recover earlier levels depends partly on how overvalued the market was in the late 1990s. As shown by Jagannathan et al (2000) the risk premium of equities over bonds can be proxied by the dividend yield plus expected dividend growth less the real bond yield. IMF (2001) argue that the growth in potential output can be used to proxy expected earnings and dividend growth.

Table 10

Estimated equity risk premia

\begin{tabular}{|l|c|c|c|c|c|}
\hline & Germany & US & UK & France & Canada \\
\hline $1960-69$ & 7.6 & 4.4 & 4.5 & 6.6 & 5.1 \\
\hline $1970-79$ & 5.8 & 7.5 & 9.4 & 11.4 & 7.6 \\
\hline $1980-89$ & 2.3 & 1.8 & 3.2 & 4.1 & 1.1 \\
\hline $1990-94$ & 0.8 & 1.7 & 1.9 & -0.3 & -1.2 \\
\hline $1995-99$ & 0.4 & 0.4 & 1.6 & -0.1 & -0.6 \\
\hline & & & & & \\
\hline Memo: 1972 & 5.9 & 3.5 & 4.3 & 8.9 & 5.3 \\
\hline Memo: 1999 & 0.0 & -0.4 & 1.0 & -0.4 & -0.1 \\
\hline
\end{tabular}

Source: Barrell and Davis (2003)

Accordingly, Table 10 below shows a measure of the risk premium using a Hodrick Prescott filter on GDP growth to proxy dividend growth. The stylised fact that premia declined in the 1980s and virtually disappeared in the $1990 \mathrm{~s}$ is confirmed. The sizeable estimated risk premium in the low- 
inflation 1960s shows that the decline is not merely a consequence of the impact of disinflation on real bond yields. The peaks of the bull markets in 1972 and 1999 show vast differences in estimated risk premia, albeit in each case generally below the decade-average, underpinning the suggesting of a bubble in 1999-2000. The US and France showed particularly low risk premia, although in all the countries shown it was at or below $1 \%$.

It is clear that underfunding in the 1980s and 1990s is partly related to overestimates of sustainable asset returns. This is a problem that also affects personal pensions, projected returns from which were even as late as 1999 permitted to be $9 \%$ (Alfon 2002). Table 11 shows that asset returns over the longer period fell far short of those available over 1975-99, and which appear to have been regarded as normal by pension providers in recent years.

Table 11: UK real equity and bond yields

\begin{tabular}{|l|c|c|}
\hline percent & Bonds & Equities \\
\hline $1871-1974$ & 1.9 & 6.7 \\
\hline $1975-1999$ & 3.3 & 11.8 \\
\hline $1871-1999$ & 2.2 & 7.6 \\
\hline
\end{tabular}

In the longer term, future asset prices could come under downward pressure as OECD population ages (affecting UK via integrated capital markets). Underlying factors include lower real returns on capital as economic growth declines and the capital/labour ratio rises; lower saving (in the "baby bust") affecting real interest rates or risk premium, and a switch from equities to bonds as the population ages. In Davis and Li (2003) we have estimated equations for equity prices and bond yields which demonstrate the role over 1950-99 of the shares in the population of 20-39 (low saving), 40-64 (high saving) and $65+$ (zero or negative saving).

\section{Chart $1 \quad$ Projected US asset prices}

\section{Real equity prices}

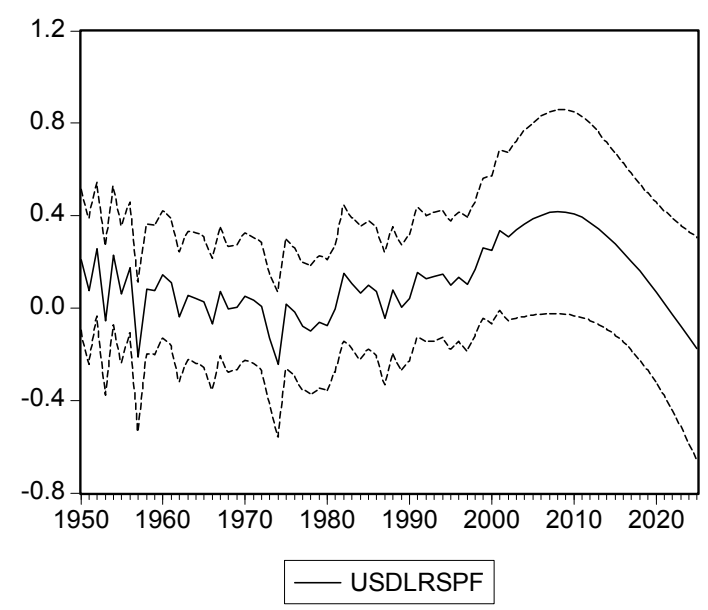

\section{Real bond yields}

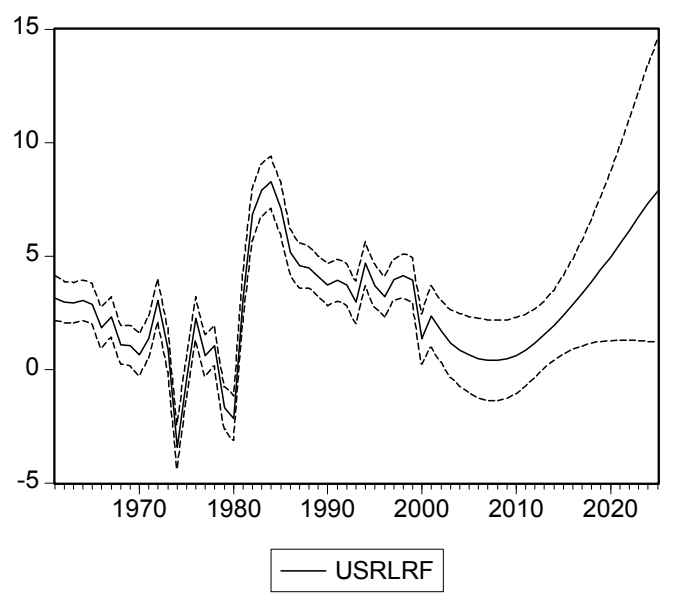

Source: Davis and Li (2003). Dotted lines are 95\% confidence bands. 
The charts show projections for US equity prices and bond yields, varying only the demographics composition of the population in line with UN (1998) projections. It can be seen that equity prices come under strong downward pressure, as in due course do bond prices (driving up bond yields). There are various offsetting factors (issuance, demand from EMEs) that mean the scenarios shown are unlikely to be precisely reproduced. But the risk underlines the need for adequate private saving - and more public provision than at present in the UK.

\section{Other issues}

There are a number of additional issues in UK pensions which, while not warranting coverage as a "crisis" at present, can affect the efficiency of the system and hence an overall evaluation. One is surplus ownership (in a bull market), see Davis (2001). More relevant at present are capital market issues. There is for example the issue of whether pension funds are or should be obliged to take a position on issues on which they have a right to vote as shareholders. This has historically not been regulated in the UK, while in the US, the Department of Labor has set out guidelines making it obligatory for pension funds to vote so-called proxy motions and hence exert "voice" in the affairs of the companies they own. Myners proposes similar legislation on corporate governance in the UK. A survey of the literature on the effects of "corporate governance activity" on equity returns (Davis and Steil 2001) suggest that the effects, if positive, are not large. There may, of course, be wider economic benefits as suggested in Davis (2002b), who showed that a high institutional share of corporate equity can accompany increased productivity growth in an economy.

Three aspects of the capital market behaviour of pension funds are widely seen as deleterious for operation of UK capital markets. One is unwillingness to invest in small firms - on the grounds they are illiquid and costly to research. Indeed, in early 2003 UK life insurers and pension funds invested only $£ 5.6$ bn in UK unquoted shares compared to $£ 367.6$ bn in quoted UK shares. This may distort the UK economy away from small firms which often generate employment and new products. Second there is the charge that pension funds cause capital market volatility as they "herd" in and out of markets, both domestically and internationally, leading to price volatility and/or liquidity failure (Davis 2002c). Third, there is the issue of "short termism" - pension funds only aim for profits in the short run and penalise long term investment (e.g. by selling to takeover raiders). Miles (1993) provides some empirical evidence that favours this hypothesis.

\section{The optimality of the UK pension system}

We can now briefly evaluate the UK pension system according to the criteria set out at the start. In terms of retirement income security, the system is showing increasingly poor performance, owing to 
low levels of private pension saving, inadequate funding and regulation of defined benefit funds, the switch to defined contribution and reduced employer contributions, and low social security provision. In terms of financing issues and sustainability, public pensions are arguably financially but not politically sustainable - while private funds are proving unsustainable in current market and regulatory situation.

Meanwhile, there is less strong evidence of labour market distortion except for portability losses in defined benefit funds - and here switch to defined contribution, as well as indexation of benefits for early leavers - are beneficial. Defined contribution funds will also reduce incentives to early retirement. Finally for capital markets, pension funds help to generate high equity inflows to UK markets but pension funds also arguably fail to invest in small firms and in long term projects, aggravate volatility. And the system as a whole, including means tested social security, may be responsible for contributing to low overall saving, affecting capital markets.

\section{Is there a UK pensions crisis?}

Coming to a conclusion, we have seen that in some areas the UK system remains satisfactory, as noted above. But there are both current and prospective difficulties that suggest, as noted above, that the system is either not sustainable or will not provide adequate retirement incomes in its current form. These vary from the current funding problems of defined benefit funds and their ongoing abandonment to difficulties in social security, annuities, contributions and overall saving.

In our view, many of the problems link to the high level of reliance on voluntary funding, low public pensions and means tested benefits for those without pension funds. Underlying aspects include inter alia inadequate pensions for those dependent on social security; exposure of funded schemes to asset price volatility now; an excessive burden of indexed defined benefit pensions to firms; inadequate contributions to defined contribution and personal funds; exposure to market failures and risks in annuities, all potentially worsening in the future as the OECD population ages. Many of these offer lessons to other countries seeking to develop funded systems.

Meanwhile, we have suggested that reforms to date are either insufficient (e.g. stakeholder pensions and scheme specific funding requirements) or even counter productive (e.g. insurance and tax ceilings). Various reforms may be suggested to improve the situation.

Beginning with parametric reforms, to limit the decline of defined benefit funds, some have proposed to reduce the scope of inflation protection to $2.5 \%$ so that the accrued benefit obligation is diminished. Alternatively, there could be unbundling of the guarantees that defined benefit funds offer (against longevity risk, inflation risk, investment risk), with individuals focusing on a subset that is most 
important to them, thus reducing costs to companies. Or defined benefit schemes could offer guarantees only up to a certain real salary, above which returns would be on a defined contribution basis.

The issue of commission costs for defined contribution schemes could be addressed via a government clearing house for contributions as in Sweden, offering economies of scale. Misselling could be reduced by shifting from front end commissions to commissions distributed over the life of the product, in line with the products performance. This would better align incentives of the salesman and consumer. We would recommend further development of the reverse mortgage market in the UK to ease liquidation of housing equity. Furthermore, there is a need for better public education and access to advice in retirement planning. Given the market failures that pervade the market for education and advice, a government subsidy for such activity may even be needed, which could usefully take place in schools and the workplace.

There is a need to take an overall view of the impact of government policies on pensions, as for example high student fees now being introduced - and consequent debts - may deter individuals from making the most remunerative pension contributions for defined contribution schemes, early in the working life ${ }^{5}$. Means testing of the pension credit discourages saving by low income households.

Following on from the assessment of crisis above, there are at least two systemic shifts that could be considered. One is a boost in the level of basic social security to levels typical of countries such as the Netherlands and the United States, thus providing an adequate basic income for all. This would have to be combined with an elimination of means testing, which would boost voluntary pension saving and eliminate the uncertainty for lower income workers as to whether saving is worthwhile. Although the overall cost of universal provision would be higher, the normal income tax system would return much of the benefit from higher income earners to the exchequer. Also retirement ages could justifiably be linked to longevity, reducing fiscal costs. With a more generous basic pension, the pressure on private pension schemes to provide very large and indexed pensions would be lessened.

A possible alternative is compulsory contributions to private pensions including compulsory and adequate employer contributions to private pensions. Switzerland and Australia are among OECD countries adopting this approach. This would inter alia ameliorate adverse selection in annuities and ensure adequate retirement saving Compulsion is needed if the view that individuals are myopic in their pension saving is taken seriously; and the evidence seems quite strong (for example the number of individuals accumulating clearly inadequate personal pensions). Besides ensuring adequate saving, compulsion would also avoid the biases in coverage (men, high earners, unionised and white collar

\footnotetext{
${ }^{5}$ This is because early contributions have the longest time to cumulate. Blake (2000) shows that $10 \%$ of salary is all that is needed for a replacement ratio of $2 / 3$ beginning at age 20 on reasonable return and earnings projections, while at 35 it is $17 \%$.
} 
workers etc.) that tend to occur when schemes are voluntary, and would facilitate job mobility by standardising terms and conditions. Notably for personal pensions, compulsory participation should help to avoid adverse selection problems which typify free markets in annuities. It could be argued that if pension funds are compulsory, then relative tax advantages are not needed, and all forms of saving should ideally receive expenditure-tax treatment. Of course the effect on overall saving would not be one-to-one as voluntary saving would fall to partly offset compulsion (Bosworth and Burtless 2003). Compared to a moderate expansion of social security, this approach would offer less diversification between risks of funding (asset returns) and pay-as-you-go (political and demographic risk).

\section{References}

Alfon I (2002), "To switch or not to switch, that is the question", Occasional Paper No 18, Financial Services Authority

Barrell R and Davis E P (2003), "Shocks and Shock Absorbers: The International Propagation of Equity Market Shocks and the Design of Appropriate Policy Responses", presented at NIESR conference "Macroeconomics and the Policy Process", 14/5/03

Blake D (2000), “'Does it matter what type of pension scheme you have?", Economic Journal, 110, F45-F81

Blake D (2003), “The UK pension system; key issues”, Pensions, 8, 330-375

Blake D and Orszag J M (1997), "Portability and preservation of pension rights in the UK", Report of the Director-General's Inquiry into Pensions, Volume 3, Office of Fair Trading, London

Bodie Z and Merton R C (1992), "Pension benefit guarantees in the United States; a functional analysis", in ed. R Schmitt "The future of pensions in the United States", University of Pennsylvania Press.

Bosworth B and Burtless G (2003), "Pension reform and saving", mimeo, Brookings Institute

Cardinale M, Findlater A and Orszag M (2002), "Paying out pensions; a review of international annuities markets", Research Report 2002-RU07, Watson Wyatt, Reigate.

CBI (2003), "Focus on investment; the impact of pension deficits", Economic Brief, July 2003, Confederation of British Industry

Cook M and Johnson P (2000), "Saving for retirement - how taxes and charges affect choice", FSA Occasional Paper No 8

Davis E P (1997), "Private pensions in OECD countries; the United Kingdom", Labour Market and Social Policy Occasional Paper No. 21, OECD, Paris

Davis E P (1998), "Policy and implementation issues in reforming pension systems", Working Paper No. 31, European Bank for Reconstruction and Development, London

Davis E P (2001), "Regulation of Private Pensions - A Case Study of the United Kingdom", Occasional Paper No OP15, Financial Services Authority, London

Davis E P (2002a), "Issues in the regulation of annuities markets", Working Paper, Center for Research on Pensions and Welfare Policies, Turin

Davis E P (2002b), "Ageing and financial stability", in eds Auerbach A and Herrmann H, "Ageing, monetary policy and financial markets", Springer, Berlin

Davis E P (2002c), "Institutional investors, corporate governance, and the performance of the corporate sector", Economic Systems, 26, 203-229

Davis E P (2003a), "Comparing bear markets, 1973 and 2000", National Institute Economic Review, 183, 78-89

Davis E P (2003b), "Fees worsen worker-student relations", Letter to Financial Times; Feb 08, 2003

Davis E P and Li C (2003), "Demographics and asset prices in the major industrial economies", Brunel University Working Paper 
Davis E P and Steil B (2001), "Institutional investors", MIT Press, Cambridge, Mass

Daykin C (2002), "Pension systems; the EU and accession countries, lessons for the UK", Politeia, London

Department of Work and Pensions (2002a), "Pensioners' income series 2000/1”, DWP, London

Department of Work and Pensions (2002b), "Simplicity, security and choice (the UK Pensions Green Paper)", DWP, London

Economist (2003a), "Retirement blues”, The Economist, 30 July 2003

Economist (2003b), "Pension pain; who is to blame for the big hole in many pension funds?", The Economist, 3 July 2003

EPC (2002), "Budgetary challenges posed by ageing populations", Economic Policy Committee, European Commission

Financial Times (2003), "Labour under fire over pensions”, FT Fund Management Supplement, 29 September 2003

FSA (2002a), “The future regulation of insurance”, Financial Services Authority, London

FSA (2002b), "Financing the future: Mind the gap!", Financial Services Authority, London

Fukao M (2002), "Barriers to financial restructuring; Japanese banking and life insurance industries", paper presented at the NBER conference on "Structural impediments to growth in Japan", Tokyo, March 18-19 2002

Government Actuary (2003), “Occupational pension schemes 2000, eleventh survey by the Government Actuary”, Government Actuary’s Department , London

HM Treasury (2002), “The Sandler Review; medium and long term retail saving in the UK”, HM Treasury

Inland Revenue, (2002), "Simplifying the taxation of pensions; increasing choice and flexibility for all”, Inland Revenue, London

International Monetary Fund (IMF), (2001), “Asset Prices and the Business Cycle,” in World Economic Outlook, April, 101-149.

Jagannathan R, McGrattan E and Scherbina A (2000), “The declining US risk premium”, Federal Reserve Bank of Minneapolis Quarterly Review, 24/4, 3-19

Lunde A, Blake D and Timmermann A (1999), The Hazards of Mutual Fund Underperformance: A Cox Regression Analysis, Journal of Empirical Finance, 6, 121-152

Mercer (2003), "Update - simplicity security and choice (comment on the Pensions Green Paper)", Mercer Human resources Consulting

Miles D (1993), “Testing for short termism in the UK stock market”, Bank of England Working Paper No. 4

Myners P (2001), “Report on Institutional Investment” HM Treasury, London

Neale I (2000), “Reframing the annuity problem - can we afford retirement?”, Journal of Pensions Management, $5,285-291$

Oliver, Wyman (2001), “The future regulation of UK savings and investment”, Oliver, Wyman and Co, London

Pensions Policy Institute (2003), “The pensions landscape”, PPI, London

Smith S and McKay S (2002), "Employers' pension provision 2000”, Research Report No 163, Department of Work and Pensions

Valdes Prieto S (1998), "Risks in pensions and annuities; efficient designs", Human Development Network, The World Bank 